\title{
EFFECTIVITY OF PIEZOELECTRIC TRANSITION ELEMENTS IN MODELLING OF ELECTRO-MECHANICAL SYSTEMS
}

\author{
Magdalena Zielińska ${ }^{a^{*}}$, Grzegorz Zboiński ${ }^{\mathrm{b}}$ \\ a Department of Mechanics and Foundations of Machines Construction, University of Warmia and \\ Mazury in Olsztyn, Olsztyn, Poland, e-mail: m.nosarzewska@uwm.edu.pl, ORCID 0000-0002- \\ $8702-6558$ \\ b Institute of Flow Machines of the Polish Academy of Sciences in Gdansk, Poland; e-mail: \\ zboi@imp.gda.pl, ORCID 0000-0001-7775-2436
}

*Corresponding author: e-mail: m.nosarzewska@uwm.edu.pl

\begin{tabular}{|c|c|}
\hline ARTICLE INFO & ABSTRACT \\
\hline $\begin{array}{l}\text { Article history: } \\
\text { Received: March } 2019 \\
\text { Received in the revised form: } \\
\text { May } 2019 \\
\text { Accepted: May } 2019 \\
\end{array}$ & \multirow{2}{*}{$\begin{array}{l}\text { The paper presents the coupled electro-mechanical problem. In the } \\
\text { numerical analysis of the issue, piezoelectric solid-to-shell transition } \\
\text { elements were applied. They combine three-dimensional or hierar- } \\
\text { chical shell piezoelectric elements with piezoelectric first order ele- } \\
\text { ments. The mentioned first order of the element refers to the field of } \\
\text { transversal displacements of an element. The mechanical field of the } \\
\text { discussed piezoelectric elements may correspond to: the model of } \\
\text { three-dimensional theory of elasticity, hierarchical shell models of } \\
\text { higher orders or the first order shell model. The electrical field of the } \\
\text { potential may be modelled with hierarchical dielectric first order } \\
\text { models or higher in transverse direction or with a three-dimensional } \\
\text { theory. Effectiveness of modification of algorithms of classical pie- } \\
\text { zoelectric elements was assessed in this paper. To perform such an } \\
\text { assessment, curves of convergence of } h p \text { method in model tasks are } \\
\text { presented. Curves obtained with the use of classical and modified } \\
\text { piezoelectric transition elements were set and compared. }\end{array}$} \\
\hline $\begin{array}{l}\text { Key words: } \\
\text { finite elements method, } \\
\text { piezoelectric elements, } \\
\text { transition models, } \\
\text { numerical solution convergence }\end{array}$ & \\
\hline
\end{tabular}

\section{Introduction}

Solid-to-shell piezoelectric transition elements are used for combining threedimensional piezoelectric elements with piezoelectric first order elements. The determined first order refers to the mechanical field of transversal displacements of an element. These displacements are linear and elastic, they can correspond to the shell first order model (or higher) or to the three-dimensional theory of elasticity. The electrical field of the potential corresponding to linear dielectricity may be immediately modelled with hierarchical models of first order dielectrics or higher ones or with the three-dimensional theory. Both fields are coupled together through constitutive piezoelectric relations where piezoelectric constants appear. The suggested manner of modelling may be used in the numerical analysis of piezoelectric transducers (sensors and actuators) (Preumont, 2002; Preumont, 2006). 


\section{Piezoelectric transition models}

A transitional nature of the elastic field of displacements may correspond to three approaches. The first one, a classical approach was discussed in (Zielińska and Zboiński, 2018). The second option (Nosarzewska and Zboiński, 2009) of the transition element in the mechanical approach was discussed in (Zielińska and Zboiński, 2011). While, the third improved option of the transition element was presented in (Zielińska and Zboiński, 2018).

\section{Classical piezoelectric transition model}

The first (classical and the simplest) approach to the transitional nature of the mechanical field assumes the continuity of the displacement field on the boundary of basic models (three-dimensional or hierarchical and the first order ones) and the transition model. This approach also assumes the continuity of the condition of lack of elongation of straight lines to the middle surface on the boundary of shell and transition models. This condition is mandatory which results in occurrence of the internal boundary layer.

In the classical case, in the piezoelectric transition model, the following constitutive relations are obligatory:

$$
\begin{aligned}
& {\left[\begin{array}{l}
\sigma_{1 \prime 1 \prime} \\
\sigma_{2 \prime 2 \prime} \\
\sigma_{3 \prime 3 \prime} \\
\sigma_{1 \prime 2 \prime} \\
\sigma_{2 \prime 3 \prime} \\
\sigma_{3 \prime 1} \prime
\end{array}\right]=\frac{E}{(1+v)(1-2 v)}\left[\begin{array}{cccccc}
1-v & v & v & 0 & 0 & 0 \\
v & 1-v & v & 0 & 0 & 0 \\
v & v & 1-v & 0 & 0 & 0 \\
0 & 0 & 0 & \frac{1-2 v}{2} & 0 & 0 \\
0 & 0 & 0 & 0 & \frac{1-2 v}{2} & 0 \\
0 & 0 & 0 & 0 & 0 & \frac{1-2 v}{2}
\end{array}\right]\left[\begin{array}{c}
\varepsilon_{1 \prime 1 \prime} \\
\varepsilon_{2 \prime 2} \\
\varepsilon_{3 \prime 3 \prime} \\
\varepsilon_{1 \prime 2 \prime} \\
\varepsilon_{2 \prime 3 \prime} \\
\varepsilon_{3 \prime 1} \prime
\end{array}\right]-} \\
& {\left[\begin{array}{ccc}
0 & 0 & C_{1 \prime 3 \prime} \\
0 & 0 & C_{2 \prime 3 \prime}^{\prime} \\
0 & 0 & C_{3 \prime 3 \prime} \\
0 & 0 & C_{4 \prime 3 \prime} \\
C_{5 \prime 1 \prime} & C_{5 \prime 2 \prime} & 0 \\
C_{6 \prime 1 \prime} & C_{6 \prime 2 \prime} & 0
\end{array}\right]\left[\begin{array}{l}
E_{1^{\prime}} \\
E_{2^{\prime}} \\
E_{3^{\prime}}
\end{array}\right]} \\
& {\left[\begin{array}{l}
d_{1^{\prime}} \\
d_{2^{\prime}} \\
d_{3^{\prime}}
\end{array}\right]=\left[\begin{array}{cccccc}
0 & 0 & 0 & 0 & C_{5^{\prime} 1^{\prime}} & C_{6^{\prime} 1^{\prime}} \\
0 & 0 & 0 & 0 & C_{5^{\prime} 2^{\prime}} & C_{6^{\prime} 2^{\prime}} \\
C_{1^{\prime} 3^{\prime}} & C_{2^{\prime} 3^{\prime}} & C_{3^{\prime} 3^{\prime}} & C_{4^{\prime} 3^{\prime}} & 0 & 0
\end{array}\right]\left[\begin{array}{c}
\varepsilon_{1^{\prime} 1^{\prime}} \\
\varepsilon_{2^{\prime} 2^{\prime}} \\
\varepsilon_{3^{\prime} 3^{\prime}} \\
\varepsilon_{1^{\prime} 2^{\prime}} \\
\varepsilon_{2^{\prime} 3^{\prime}} \\
\varepsilon_{3^{\prime} 1^{\prime}}
\end{array}\right]+\left[\begin{array}{ccc}
\gamma_{1^{\prime} 1^{\prime} 1} & \gamma_{1^{\prime} 2^{\prime}} & 0 \\
\gamma_{2^{\prime} 1^{\prime}} & \gamma_{2^{\prime} 2^{\prime}} & 0 \\
0 & 0 & \gamma_{3^{\prime} 3^{\prime}}
\end{array}\right]\left[\begin{array}{c}
E_{1^{\prime}} \\
E_{2^{\prime}} \\
E_{3^{\prime}}
\end{array}\right]}
\end{aligned}
$$

In the equation (1) of the mechanical field, values $\sigma_{i{ }^{\prime}{ }^{\prime}}$ and $\varepsilon_{i^{\prime} j^{\prime}}, i^{\prime}, j^{\prime}=1,2,3$, are stress tensors and strains in the local system of the shell. In this system, two first directions are longitudinal and the third one is transverse. $E$ and $v$ constants are Young modulus and Poisson ratio. Equation (1) is coupled with equation (2) of the electrical field through piezoelec-

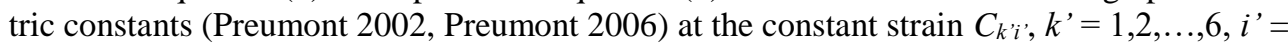


$1,2,3$, corresponding to the local system of the piezoelectric shell. In the equation (2) values $E_{i}$, and $d_{i}, i^{\prime}=1,2,3$, are components of the vector of an electric field, while $\gamma_{i^{\prime} j^{\prime},}, i^{\prime}, j^{\prime}=$ 1,2,3 are dielectric constants at the constant strain (Preumont 2002, Preumont 2006), defined in the local system.

\section{Modified classical piezoelectric transition model}

The second (modified) approach to the transitional character of the mechanical field was presented in (Zielińska and Zboiński, 2019). In this approach, except for assumptions that are mandatory in the classical approach, continuity of the field of stresses between basic models was assumed. This was obtained through a variable definition of elastic constants in the transition model which corresponds to the transition from the shell to three-dimensional state of stresses.

In case of piezoelectric elements, due to coupling of the mechanical and electrical field, applicable conditions in the mechanical model also modify electrical fields, i.e.:

$$
\begin{aligned}
& {\left[\begin{array}{l}
\sigma_{1 \prime 1 \prime} \\
\sigma_{2 \prime 2 \prime} \\
\sigma_{3 \prime 3 \prime} \\
\sigma_{1 \prime 2 \prime} \\
\sigma_{2 \prime 3 \prime} \\
\sigma_{3 \prime 1 \prime}
\end{array}\right]=}
\end{aligned}
$$

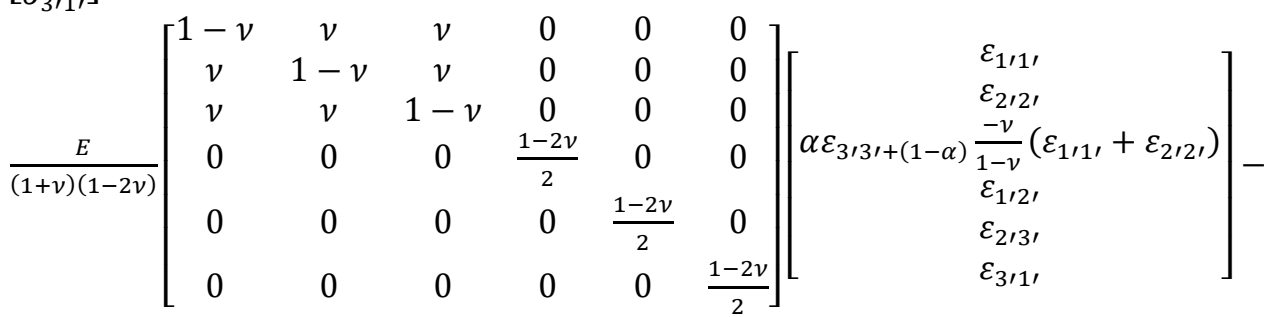

$$
\begin{aligned}
& {\left[\begin{array}{ccc}
0 & 0 & C_{1^{\prime} 3^{\prime}}-(1-\alpha) \frac{v}{1-v} C_{3^{\prime} 3^{\prime}} \\
0 & 0 & C_{2^{\prime} 3^{\prime}}-(1-\alpha) \frac{v}{1-v} \frac{v}{1-v} C_{3^{\prime} 3^{\prime}} \\
0 & 0 & 0 \\
0 & 0 & C_{4^{\prime} 3^{\prime}} \\
C_{5^{\prime} 1^{\prime}} & C_{5^{\prime} 1^{\prime}} & 0 \\
C_{6^{\prime} 1^{\prime}} & C_{6^{\prime} 2^{\prime}} & 0
\end{array}\right]\left[\begin{array}{l}
E_{1^{\prime}} \\
E_{2^{\prime}} \\
E_{3^{\prime}}
\end{array}\right]}
\end{aligned}
$$

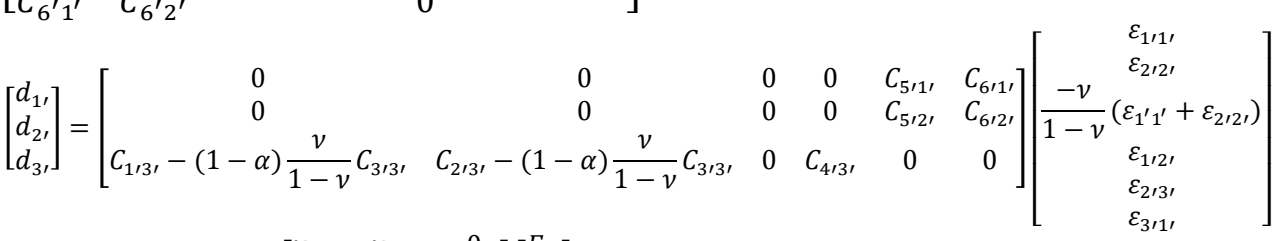

$$
\begin{aligned}
& +\left[\begin{array}{ccc}
\gamma_{1 \prime 1 \prime}, & \gamma_{1 / 2 \prime} & 0 \\
\gamma_{2 \prime 1 \prime} & \gamma_{2 \prime 2 \prime} & 0 \\
0 & 0 & \gamma_{3 \prime 3 \prime}
\end{array}\right]\left[\begin{array}{l}
E_{1 \prime} \\
E_{2 \prime} \\
E_{3 \prime}
\end{array}\right]
\end{aligned}
$$


A variable character of the elastic constants was included by introduction of a corrective function of transition $\alpha$ to the constitutive equations (3)-(4). This function assumes value 0 in the shell first order elements and on the edge of the shell part of the transition model, while value 1 for the three-dimensional element. In the transition part, intermediate values from the range $(0,1)$ are assumed.

\section{Numericl analysis}

Numerical tests were carried out by analysis of piezoelectric square plate with the side $l$ and thickness $t$, clamped along four lateral sides, and loaded with a constant vector of superficial forces $\boldsymbol{p}$ (fig. 1). A symmetric nature of geometry, loading, and boundary conditions enabled to include in calculations only a fourth part of the structure. Due to a transverse nature of the loading, the plate has a bending-dominated nature (predominance of bending strains).

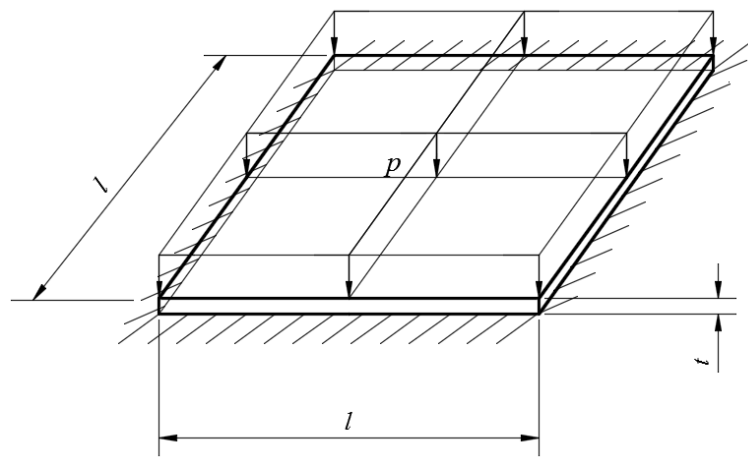

Figure 1. Loading and manner of supporting the square plate

The electrical field of the piezoelectric plate corresponds to the grounding of the side surfaces. On the top surface of the piezoelectric plate there are external surface charges of the constant value $c$. Symmetry of the electric field enables analysis of the quarter of the plate similarly as in case of the mechanical field.

In the presented part of the numerical analysis, a regular mesh of prismatic elements was applied (fig.2). The structure includes the following mechanical models: threedimensional (3D - yellow, orange), Reissner-Mindlin shell model (RM - blue colours) and a transition model (TR $\equiv \mathrm{RM} / 3 \mathrm{D}$ - green). In the electrical field only one dielectric model of a hierarchical nature was applied. It was marked with (EJ) symbol. The mentioned models were presented in the papers (Zboiński, 2001; Zboiński, 2016; Zboiński, 2018). On the left side of the figure, mechanical models (3D, RM/3D, RM) were presented, while on the right side, the corresponding piezoelectric models (EJ,3D; EJ, RM/3D; EJ, RM). Division into zones that correspond to particular models was carried out parallel to the lateral sides with a variable participation of the shell and the three-dimensional parts in the complex structure. 


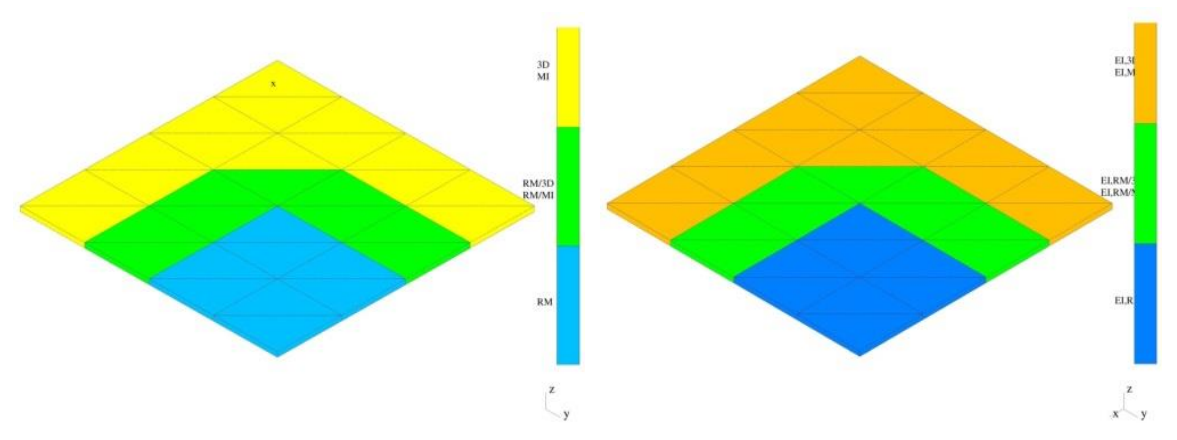

Figure 2. Symmetrical quarter of the complex piezoelectric structure

\section{Convergence of the solution in model problems}

Convergence of the numerical solution was presented in the form of the so-called curves of convergence. These curves were formed by drawing a graphic relation between a real error of approximation of the solution, determined as an energy difference $\left(V_{R}-V\right)$, and the number of degrees of freedom $N$ at the fixed division of the mesh and a variable order of longitudinal approximation, $p=1,2, \ldots, 8$. Transverse and longitudinal orders of approximation, both in the mechanical and electric field, were the same. In the numerical analysis, a determined value of the transverse order of approximation corresponding to the mechanical model in the element was used i.e. $q=1$ or $q=2$. In the difference of energies, $V_{R}$ denotes electro-mechanical potential energy which constitutes the reference, while $V$ means electro-mechanical potential energy from a particular calculation case. The potential energies are defined here as equal to strain energy reduced by energy of the electric field and energy of electro-mechanical coupling. As it is impossible to obtain an accurate value of the reference energy, we will assume it as corresponding to the value of the best numerical solution.

Particular curves of convergence (Fig. 3) correspond to the raising participation of the piezoelectric shell element (RM) in the three-dimensional (3D) piezoelectric structure. It is accompanied by a change of the transverse approximation order from the value $q=2$, applicable in the three-dimensional and transition part (TR), to the value $q=1$ corresponding to the piezoelectric shell Reissner-Mindlin model. Particular points of given curves correspond to the variable number of degrees of freedom that depend on the assumed order of longitudinal approximation in the structure $(p=1,2, \ldots, 8)$.

In figure 3 and 4, a curve marked with violet (_1) corresponds to a mesh with two shell elements in the structure. A light blue curve (_2) is a curve with 8 shell elements in the structure. In turn, an orange curve (_3) corresponds to the plate structure with 18 shell elements. 
Magdalena Zielińska, Grzegorz Zboiński

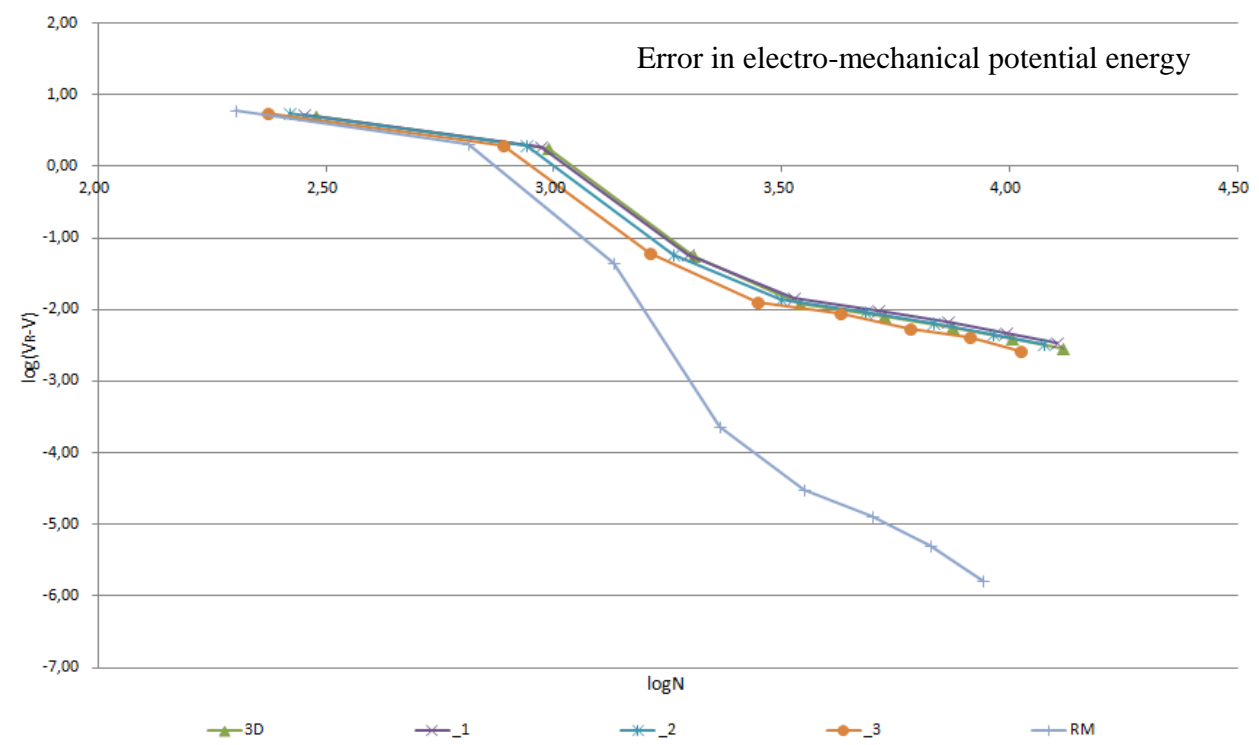

Figure 3. Convergence curves - classical piezoelectric transition model

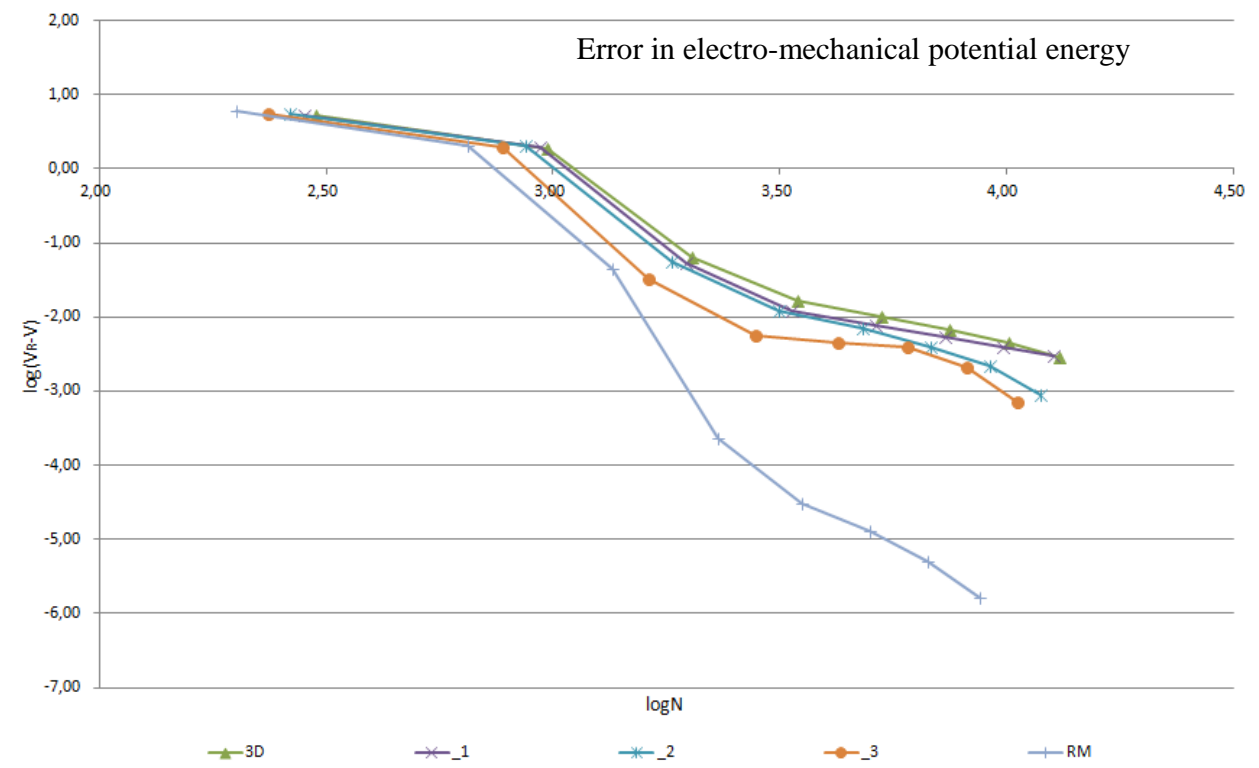

Figure 4. Curves of convergence - modified piezoelectric transition model 
Convergence of solution (curves slope) in case of complex (mixed) models with participation of transition elements are similar to curves for the basic three-dimensional model of piezoelectric theories. Three-dimensional elements (more precisely, identical to hierarchical shell elements MI with order $I=q$ ) located on lateral sides, and subject to presence of the external boundary layer phenomenon, decide on the convergence in each analysed case (Miazio, 2002). In case of Reissner-Mindlin basic model, this phenomenon does not occur and thus there is a difference of the corresponding convergence curves in this case.

Moreover, analysis of the above two sets of curves enables to notice that in case of the use of the modified piezoelectric transition element (Fig. 4) systematisation of the curves course took place in comparison to the case when the classical model was used (Fig. 3). The introduced modification caused that the curves obtained for the complex models of the plate (including transition models) do not cross with each other and with curves of the structures modelled by means of basic models. Moreover, curves of complex models are located between curves of basic models of the plate only when modified transition elements are applied. We may notice that changes introduced in these elements, in comparison to the version of the element stabilise numerical algorithms of transition elements.

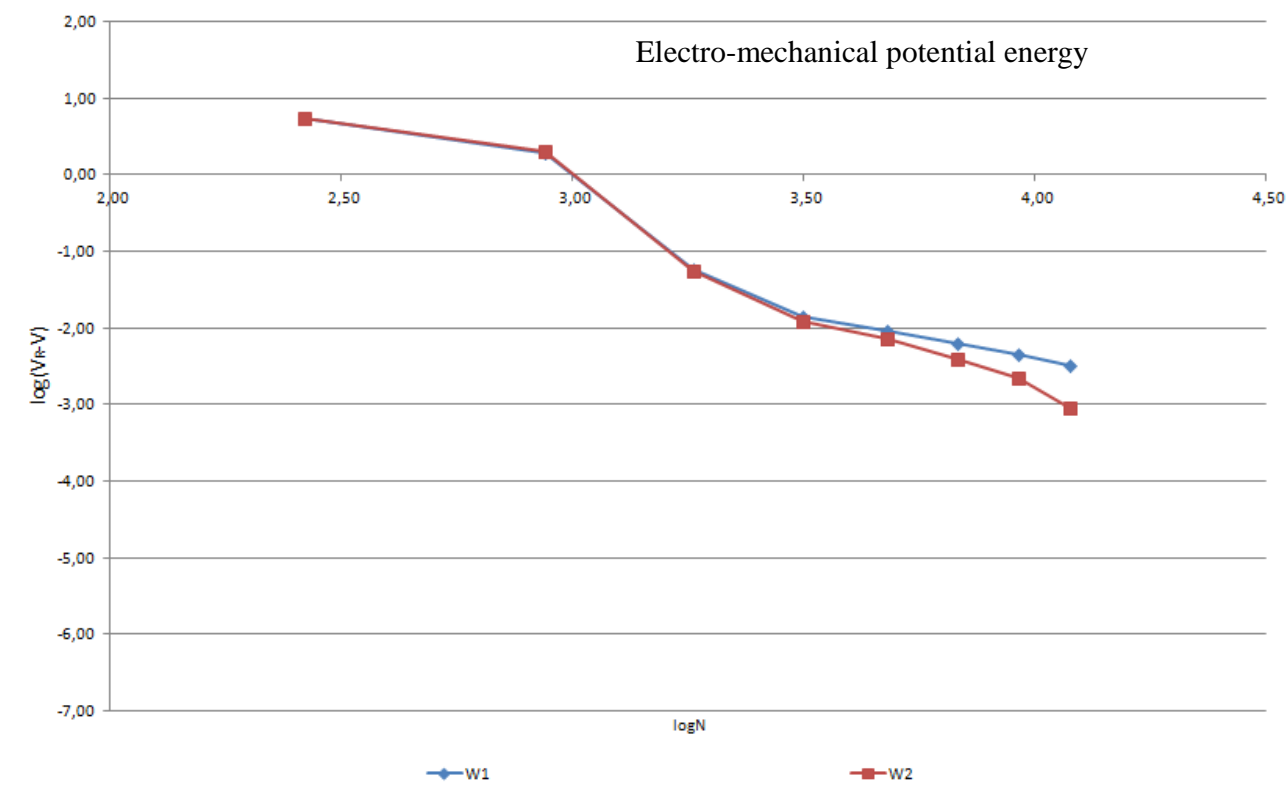

Figure 5. Curves of convergence - comparison of convergence

In order to present the improvement of convergence more precisely, one curve obtained for the mixed structure, presented in figure 2, was selected. A curve obtained at application of the classical piezoelectric transition element is marked in figure 5 with blue (marked as 
W1 on the graph). Whereas, a brown curve (marked as W2) corresponds to application of the modified piezoelectric transition element.

\section{Conclusion}

Based on the numerical analysis that was carried out, we may conclude that the classical version of the piezoelectric transition element ensures continuity of the field of displacements on the boundary between mechanical basic models and a transition element and continuity of the field of the potential in the electric field. It required to include ReissnerMindlin relations not only in the shell element but also in the shell part of the transition element. The classical piezoelectric transition model does not guarantee the continuity of the strain and stresses fields on the boundary between the shell a transition models due to different constitutive constants in the transition model and in the three-dimensional element.

The modified piezoelectric transition model, such as applied in the classical element, ensures continuity of the transition field and continuity of the field of potential on the boundary between mechanical basic models and the transition model, similarly as in the case of the classical element. Modifications introduced to the transition element guarantee continuity of the field of stress on the boundary between the shell and transition model.

We may conclude, based on the analysis of convergence of the solution, that due to the modified transition model, curves were ordered with regard to cases based on the basic models, which was not guaranteed by application of the classical piezoelectric transition element. Moreover, we may observe a slightly higher convergence of the solution for the discussed issue of the piezoelectric plate in case of application of the modified transition model instead of the classical model.

\section{References}

Miazio, Ł. (2013). Analiza struktur sprężystych z warstwa brzegowa $z$ wykorzystaniem adaptacyjnej metody elementów skończonych typu hp. Rozprawa doktorska, Instytut Maszyn Przepływowych PAN, Gdańsk.

Nosarzewska, M., Zboiński, G. (2009). Efektywność przejściowych elementów skończonych w hierarchicznym modelowaniu struktur złożonych. Modelowane Inżynierskie, 7(38). 131-138.

Preumont, A. (2002). Vibration Control of Active Structures. An Introduction. 2nd Edition. Kluwer Academic Publishers, Dordrecht, The Netherlands, ISBN 1-4020-0925-9.

Preumont, A. (2006). Mechatronics. Dynamics of Electromechanical and Piezoelectric Systems. Springer, Dordrecht, The Netherlands, ISBN 1-4020-4695-2.

Zboiński, G. (2001). Modelowanie hierarchiczne i metoda elementów skończonych do adaptacyjnej analizy struktur złożonych. Zeszyty naukowe IMP PAN $w$ Gdańsku, Studia i materiaty, 520/1479/2001, Instytut Maszyn Przepływowych PAN, Gdańsk.

Zboiński, G. (2016). Problems of Hierarchical Modelling and $h p$-Adaptive Finite Element Analysis in Elasticity, Dielectricity and Piezoelectricity. (W:) Petrova R. (red.) Perusal of the Finite Element Method. In Tech, Rijeka, 1-29.

Zboiński, G. (2018). Adaptive modeling and simulation of elastic, dielectric and piezoelectric problems. (W:) Pacurar R. (red.) Finite Element Method - Simulation, Numerical Analysis and Solution Techniques. In Tech, Rijeka, 157-192. 
Efficiency of piezoelectric...

Zielińska, M., Zboiński, G. (2011). Efektywność przejściowych elementów skończonych w modelowaniu struktur złożonych zdominowanych membranowo. Mechanik, 7, 967-972.

Zielińska, M., Zboiński, G. (2018a). Algorytm opartych na podejściu trójwymiarowym, adaptacyjnych, piezoelektrycznych elementów przejściowych. 57. Sympozjon Modelowanie w Mechanice, Zeszyt streszczeń. 130.

Zielińska, M., Zboiński G. (2018b). Solid-to-shell transition elements in adaptive analysis of model structures of a complex mechanical description. AIP Conference Proceedings, 1922, 040004.

Zielińska, M., Zboiński, G. (2019). Modyfikacja algorytmu adaptacyjnych piezoelektrycznych elementów przejściowych. 58. Sympozjon Modelowanie w Mechanice, Zeszyt streszczeń. 91-92.

\title{
EFEKTYWNOŚĆ PIEZOELEKTRYCZNYCH ELEMENTÓW PRZEJŚCIOWYCH W MODELOWANIU UKŁADÓW ELEKTRO-MECHANICZNYCH
}

\begin{abstract}
Streszczenie. Praca dotyczy sprzężonego problemu elektro-mechanicznego. W analizie numerycznej zagadnienia zastosowane zostały piezoelektryczne elementy przejściowe o charakterze bryłowopowłokowym. Łączą one ze sobą trójwymiarowe (lub hierarchiczne powłokowe) elementy piezoelektryczne z elementami piezoelektrycznymi pierwszego rzędu. Wspomniany pierwszy rząd elementu odnosi się do pola przemieszczeń poprzecznych elementu. Pole mechaniczne omawianych elementów piezoelektrycznych może odpowiadać modelom trójwymiarowej teorii sprężystości, hierarchicznym modelom powłokowym wyższych rzędów lub modelowi powłokowemu pierwszego rzędu. Elektryczne pole potencjału modelowane może być za pomocą hierarchicznych modeli dielektrycznych rzędu pierwszego lub wyższych w kierunku poprzecznym lub teorią trójwymiarową. W niniejszej pracy dokonana została ocena efektywności modyfikacji wprowadzonych do algorytmów klasycznych elementów piezoelektrycznych. W celu takiej oceny przedstawione są krzywe zbieżności metody $h p$ w zadaniach modelowych. Zestawione ze sobą i porównane zostały krzywe uzyskane z wykorzystaniem klasycznych i zmodyfikowanych, piezoelektrycznych elementów przejściowych.
\end{abstract}

Słowa kluczowe: metoda elementów skończonych, elementy piezoelektryczne, modele przejściowe, zbieżność rozwiązania numerycznego 